\title{
KEBIJAKAN PENGENDALIAN PEMANFAATAN RUANG MELALUI PENEGAKAN HUKUM PIDANA PADA PELANGGARAN RENCANA TATA RUANG DIHUBUNGKAN DENGAN UNDANG-UNDANG NO 26 TAHUN 2007 TENTANG PENATAAN RUANG
}

\author{
Andi Tenrisau \\ Program Studi Doktor Ilmu Hukum \\ Pascasarjana Universitas Islam Bandung \\ e-mail: tenrisau_sulsel@yahoo.co.id
}

\begin{abstract}
Abstrak : Peningkatan aktivitas di kawasan Jabodetabekpunjur memberikan dampak positif dan negatif. Peningkatan aktivitas dapat berdampak positif pada perkembangan ekonomi kawasan, namun disisi lain memicu pelanggaran terhadap rencana tata ruang. Kondisi ini berdampak terhambatnya kegiatan investasi, meningkatkan kerentanan masyarakat karena banyaknya kerugian yang ditanggung, dan meningkatnya tanah terlantar di kawasan perkotaan Jabodetabekpunjur. Untuk itu, pengendalian pemanfaatan ruang perlu dilakukan dan didukung oleh upaya penegakan hukum. Metode pendekatan dalam penelitian ini adalah pendekatan yuridis normatif, yaitu metode penelitian hukum yang dilakukan dengan meneliti bahan pustaka atau data sekunder. Penegakan hukum dalam pengendalian pemanfaatan ruang dipengaruhi oleh faktor hukum, faktor penegak hukum, faktor sarana atau fasilitas pendukung, faktor masyarakat, dan faktor kelembagaan. Pada prinsipnya, keselarasan antara pembangunan fisik dan pengelolaan lingkungan harus tercapai sehingga keduanya berdampak positif terhadap perekonomian kawasan.
\end{abstract}

Kata Kunci: Tata Ruang, Penegakan Hukum, Pengendalian Pemanfaatan Ruang.

Abstract : The increase of activity in Jabodetabekpunjur urban area has positive and negative impacts. Increased activity can have a positive impact on the economic development, but on the other hand lead to a violation of the spatial plan. This condition hampers investment activities, increased the community vulnerability due to the large number of losses incurred, and increased land abandoned in the Jabodetabekpunjur. Therefore, the control of the space utilization needs to be done and supported by law enforcement. The approach method in this study is a normative juridical approach, namely the method of legal research conducted by examining library materials or secondary data. Law enforcement in controlling the utilization of space influenced by legal factors, law enforcement factors, facilities or supporting facilities, community factors, and institutional factors. In principle, the harmony between physical development and environmental management must be achieved so as to have a positive impact on the regional economy.

Keywords: spatial planning, law enforcement, spatial utilization control.

\section{A. PENDAHULUAN}

Ruang merupakan tempat

berlangsungnya aktivitas yang harus diatur

pemanfaatannya secara adil demi mewujudkan kesejahteraan bersama, dalam hal ini negara mempunyai kekuasaan yang sangat besar. Dalam Undang-Undang Dasar Negara Republik Indonesia Tahun 
1945 (UUD 1945) ditegaskan, bahwa "Bumi dan Air dan kekayaan alam yang terkandung di dalamnya dikuasai oleh negara dan dipergunakan untuk sebesarbesarnya kemakmuran rakyat. Pengertian “dikuasai" dalam UUD 1945 adalah dipakai dalam aspek publik. ${ }^{1} \mathrm{Hal}$ ini berarti negara mengatur pemanfaatan ruang (bumi dan air dan kekayaan alam) untuk kesejahteraan rakyat.

Rangka mewujudkan pemanfaatan ruang yang menyejahterakan rakyat, maka disusunlah Undang-Undang Nomor 5 Tahun 1960 tentang Peraturan Dasar Pokok-Pokok Agraria (UUPA) dan Undang-Undang Nomor 26 Tahun 2007 tentang Penataan Ruang (UUPR). Keduanya mengamanatkan pentingnya suatu rencana (planning) mengenai pemanfaatan ruang agar kesejateraan rakyat dapat tercapai. UUPR menyatakan, bahwa negara menyelenggarakan penataan ruang yang pelaksanaan wewenangnya dilakukan oleh pemerintah pusat dan daerah.

Pesatnya perkembangan kawasan baik di perkotaan maupun di pedesaan, memberikan dampak positif bagi perkembangan ekonomi dan juga menyebabkan pemanfaatan ruang menjadi

1 Boedi Harsono, Hukum Agraria Indonesia: Himpunan Peraturan-Peraturan Hukum Tanah, Djambatan, Jakarta, 2008, Hlm. 23. semakin meningkat. Kondisi ini dapat memicu perubahan alih fungsi lahan lindung menjadi budidaya. Dalam kurun waktu tertentu, alih fungsi lahan sangat berpotensi mengakibatkan timbulnya permasalahan lingkungan. Hal ini terlihat dengan semakin kritisnya kondisi lingkungan di Indonesia, yang berdampak pada intensitas bencana alam yang terjadi di berbagai wilayah di Indonesia yang salah satu penyebabnya adalah pelanggaran tata ruang. ${ }^{2}$ Dengan demikian, pengendalian pemanfaatan ruang sangat penting untuk dilakukan dalam rangka menjaga kelestarian lingkungan.

Pengendalian pemanfaatan ruang diperlukan untuk mewujudkan tertib tata ruang, sebagaimana tercantum dalam Pasal 1 UUPR. Pengendalian pemanfaatan ruang dilakukan melalui implementasi 4 (empat) instrumen pengendalian yang meliputi peraturan zonasi, perizinan, pemberian insentif dan disinsentif, serta pengenaan sanksi. Pengendalian pemanfaatan ruang dapat dilakukan secara preventif (Ex Ante Factum) maupun secara reaktif/responsif (Post Factum). Pengendalian yang bersifat preventif adalah berupa peraturan zonasi,

\footnotetext{
2 Ahmad Jazuli, Penegakan Hukum Penataan Ruang dalam Rangka Mewujudkan Pembangunan Berkelanjutan, Jurnal Rechts Vinding: Media Pembinaan Hukum Nasional, 6(2), 2017, Hlm. 265.
} 
insentif dan disinsentif, izin sedangkan yang bersifat represif berupa sanksi. ${ }^{3}$

Upaya pengendalian pemanfaatan ruang tidak cukup jika hanya menggunakan pendekatan hukum, namun juga harus ada unsur kepedulian dari masyarakat. Manusia dalam kehidupannya sangat bergantung pada sumber daya alam sekitar, seperti pemanfaatan air, udara dan tanah. Jika manusia tidak dapat berperilaku sesuai nilai prinsip dan norma yang berlaku dalam memanfaatkan sumber daya alam, maka krisis lingkungan dapat terjadi, sehingga diperlukan etika lingkungan. ${ }^{4}$

Etika lingkungan merupakan ilmu tidak hanya mengatur perilaku manusia dengan alam, namun juga mengatur perilaku manusia dengan manusia dan manusia dengan mahluk lain secara keseluruhan berdampak terhadap alam. ${ }^{5}$ Sementara itu, Soerjani menjelaskan, bahwa etika lingkungan hidup merupakan bahasan mengenai hak dan kewajiban manusia terhadap lingkungan serta batasan

3 Anugerah Perkasa, Pelanggaran Tata Ruang: Data 194 Perusahaan di Kalteng dan Kalbar Diserahkan ke KPK, dari http://kabar24.bisnis.com/read/20151105/16/4890 87/. Diakses pada 26 Juli 2018 Pukul 20.00 WIB

${ }^{4}$ Andi Renald, Kota Resilien Mewujudkan Jakarta Bebas Banjir, Dirjen Pengendalian Pemanfaatan Ruang dan Penguasaan Tanah, 2017, Hlm. 37.

5 Sonny Keraf, Etika Lingkungan Hidup, Kompas, 2002, Hlm. 14. perilaku terhadap lingkungan. ${ }^{6}$ Soerjani menyatakan, bahwa dalam etika lingkungan juga berbicara mengenai peningkatkan solidaritas antara manusia dengan sesama dan tentu saja antara manusia dengan alam. Dari dua pendapat ahli tersebut dapat ditarik suatu kesimpulan, bahwa etika lingkungan adalah sistem nilai (value system) manusia untuk memperlakukan manusia berdasarkan kaidah, norma, moralias yang membatasi perilaku dan tindakan manusia terhadap lingkungan.

Pelanggaran terhadap rencana tata ruang banyak terjadi di wilayah Jakarta, Bogor, Depok, Tangerang, Bekasi, Puncak dan Cianjur (Jabodetabekpunjur). Berdasarkan data dari Kementerian Pekerjaan Umum, indikasi pelanggaran rencana tata ruang di wilayah Jabodetabekpunjur, yaitu sebanyak 788 kasus. Salah satu kasusnya adalah pembangunan vila tanpa IMB di Kawasan Puncak di Kabupaten Bogor. Berdasarkan dokumen pelaksanaan pengawasan dan pengendalian pemanfaatan ruang Jabodetabekpunjur Kementerian Pekerjaan Umum, terdapat pembangunan vila di kawasan peruntukkan hutan lindung

\footnotetext{
${ }^{6}$ Mohamad Soerjani, Ekologi Manusia, Reduction Climet Change, Adative Capacity and Development, Universitas Terbuka, TangerangJakarta, 2002, Hlm. 9.
} 
(Peruntukkan ruang menurut Perpres No. 54 Tahun 2008). Demikian juga dengan yang kasus pembangunan Casa Monte Rosa Resort di kawasan budidaya permukiman pedesaan (merujuk pada Perpres No. 54 Tahun 2008 dan Perda RTRW No. 17 Tahun 2012). Kasus ini sering terjadi mengingat permintaan penginapan di Kawasan Puncak sangat tinggi. Kasus-kasus okupasi lahan untuk daerah-daerah sempadan juga selalu terjadi, seperti yang terlihat di DKI Jakarta. Di sepanjang Sungai Ciliwung, telah banyak digunakan sebagai permukiman. Pemerintah DKI Jakarta pada dasarnya telah berupa menertibkan bangunanbangunan tersebut namun hasilnya belum memuaskan. $^{7}$

Kasus-kasus yang telah disebutkan diatas merupakan bentuk pelanggaran pemanfaatan ruang. Namun, hingga saat ini kasus-kasus pelanggaran pemanfaatan ruang sangat sedikit yang sampai pada proses di pengadilan, bahkan belum pernah ada kasus yang sampai pada penuntutan di pengadilan. Sebagai contoh kasus pembangunan vila liar di Kawasan Puncak, yang hingga saat ini belum ada yang di vonis bersalah di pengadilan. Akibatnya,

\footnotetext{
${ }^{7}$ Laporan Akhir Pelaksanaan Pengawasan dan Pengendalian Pemanfaatan Pemanfaatan Ruang Jabodetabekpunjur , Kementerian Pekerjaan Umum, Jakarta, 2013, Hlm. 36.
}

pembangunan vila tidak berizin masih terus tumbuh meskipun telah berkali kali ditertibkan. ${ }^{8}$

Uraian tersebut menunjukkan bahwa implementasi penegakan hukum pidana terhadap pelanggaran rencana tata ruang belum efektif, meskipun ancaman pidana terhadap pemanfaatan ruang yang tidak sesuai dengan rencana tata ruang telah diatur secara jelas dalam UUPR. Terdapat faktor-faktor yang menghambat atau kendala dalam penerapan hukum pidana dalam pelanggaran rencana tata ruang. Fenomena ini tentu saja menarik untuk diteliti. Dengan demikian, pernyataan masalah (problem statement) dalam penelitian ini adalah implementasi kebijakan pengendalian pemanfaatan ruang khususnya penegakan hukum pidana dalam pelanggaran terhadap rencana tata ruang belum optimal. Dimensi-dimensi dalam yang berpengaruh terhadap implementasi kebijakan penegakan hukum yang menyebabkan penegakan hukum belum efektif untuk diberlakukan perlu untuk dielaborasi. Hasil elaborasi digunakan untuk mengidentifikasi penegakan hukum pidana yang efektif dalam pengendalian pemanfaatan tata ruang dalam rangka mendukung pembangunan berkelanjutan.

\footnotetext{
${ }^{8}$ Ibid.
} 
Selanjutnya komisi sedunia untuk lingkungan dan pembangunan menyatakan, yang dimaksud dengan pembangunan yang berkelanjutan adalah pembangunan yang memenuhi kebutuhan kita sekarang tanpa mengurangi kemampuan generasi yang akan datang untuk memenuhi kebutuhan mereka. 9 Untuk dapat mewujudkan implementasi pemanfaatan ruang yang sesuai dengan Rencana Tata Ruang Wilayah (RTRW) maka diperlukan penyusunan konsep untuk mengintegrasikan faktor-faktor penegakan hukum penataan ruang menjadi suatu konsep yang efektif untuk mendukung tertib pelaksanaan pengendalian pemanfaatan ruang. Konsep tersebut diharapkan dapat berfungsi untuk menciptakan ruang hidup yang lebih baik dan memberi rasa aman dan nyaman bagi masyarakat, serta menjaga keberlanjutan fungsi-fungsi lingkungan khususnya pada kawasan perkotaan. Kerangka konsep yang komprehensif terdiri atas faktor-faktor yang berpengaruh untuk menciptakan fungsi penegakan hukum pengendalian pemanfaatan ruang. Konsep yang disusun akan dijadikan dasar untuk membangun model penegakan hukum penataan ruang

\footnotetext{
${ }^{9}$ Oto Sumarwoto, Ekologi, Lingkungan Hidup, dan Pembangunan, Alumni, Jakarta, 1997, Hlm. 162.
}

yang efektif dalam rangka mewujudkan tertib pelaksanaan rencana tata ruang.

Penyusunan penelitian penegakan hukum pidana pada pelanggaran terhadap rencana tata ruang dilakukan tahapantahapan sebagai berikut:

a) Mengidentifikasi pelaksanaan atau implementasi kebijakan penegakan hukum pidana pada pelanggaran terhadap rencana tata ruang.

b) Mengidentifikasi faktor-faktor yang berpengaruh pada pelaksana termasuk faktor-faktor penghambatnya.

c) Menyusun konsep efektif untuk menerapkan aturan hukum pidana pada pelanggaran terhadap rencana tata ruang.

Berdasarkan pemikiran tersebut, maka kebaruan (novelty) dari penelitian ini adalah

a) Konsep kerangka kerja (framework) yang menggambarkan dimensidimensi yang berpengaruh untuk mewujudkan pelaksanaan penegakan hukum pengendalian pemanfaatan ruang; dan

b) Konsep penegakan hukum pidana penataan ruang yang terbangun dapat diimplementasikan pada praktikpraktik pengenaan sanksi pidana bagi pelanggaran rencana tata ruang di Indonesia, sehingga terwujud tujuan 
penataan ruang yaitu terciptanya ruang yang aman, nyaman, produktif dan berkelanjutan.

Berdasarkan hal tersebut diatas maka penulis dapat membuat identifikasi masalah dalam pembahasan ini yaitu:

1. Bagaimana implementasi kebijakan penegakan hukum pidana pada pelanggaran terhadap rencana tata ruang?

2. Apa saja faktor-faktor yang berpengaruh terhadap implementasi kebijakan penegakan hukum pidana pada pelanggaran terhadap rencana tata ruang dalam rangka pengendalian pemanfaatan ruang?

3. Bagaimana kebijakan pengendalian pemanfaatan ruang yang dapat efektif diberlakukan melalui penegakan hukum pidana pada pelanggaran terhadap rencana tata ruang?

\section{B. HASIL DAN PEMBAHASAN}

\section{Implementasi}

Kebijakan

Penegakan Hukum Pidana Pada

Pelanggaran Terhadap Rencana

Tata Ruang

\section{a. Proses Penyusunan Rencana Tata Ruang}

Objek penegakan hukum tata ruang adalah kebijakan mengenai rencana tata ruang itu sendiri. Rencana Umum Tata
Ruang (RUTR) di Indonesia terdiri dari Rencana Tata Ruang Wilayah Nasional (RTRWN), Rencana Tata Ruang Wilayah Provinsi (RTRWP), dan Rencana Tata Ruang Kab/Kota. RUTR merupakan perangkat penataan ruang wilayah yang disusun berdasarkan pendekatan wilayah administratif yang secara hierarki terdiri atas rencana tata ruang wilayah nasional, rencana tata ruang wilayah provinsi, dan rencana tata ruang wilayah kabupaten/kota. RUTR kemudian dijabarkan menjadi Rencana Rinci Tata Ruang (RRTR) untuk mengatur wilayah secara lebih detail. RRTR disusun dengan pendekaan nilai strategis kawasan dan/atau kegiatan kawasan dengan muatan subtansi yang dapat mencakup hingga penetapan blok dan subblok yang dilengkapi peraturan zonasi sebagai salah satu dasar dalam pengendalian pemanfaatan ruang sehingga pemanfaatan ruang dapat dilakukan sesuai dengan rencana umum tata ruang dan rencana rinci tata ruang. Rencana rinci tata ruang dapat berupa rencana tata ruang kawasan strategis dan rencana detail tata ruang.

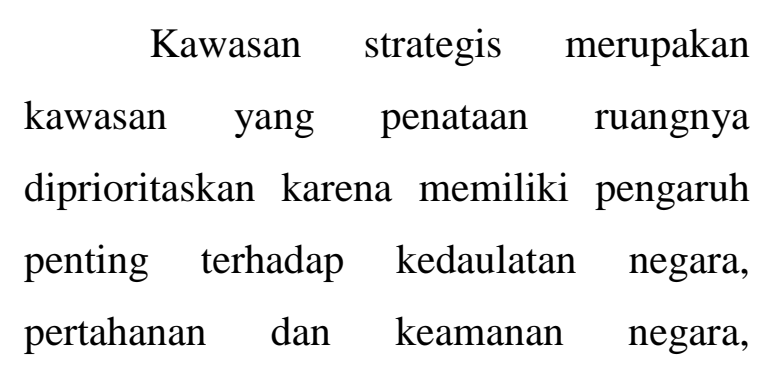


pertumbuhan ekonomi, sosial, budaya, dan/atau lingkungan termasuk wilayah yang telah ditetapkan sebagai warisan dunia. Rencana tata ruang kawasan strategis tidak mengulang hal-hal yang sudah diatur atau menjadi kewenangan dari rencana tata ruang yang berada pada jenjang di atasnya maupun di bawahnya. Adapun rencana detail tata ruang merupakan penjabaran dari RTRW pada suatu kawasan terbatas, ke dalam rencana pengaturan pemanfaatan yang memiliki dimensi fisik mengikat dan bersifat operasional. Rencana detail tata ruang berfungsi sebagai instrumen perwujudan ruang khususnya sebagai acuan dalam permberian advise planning dalam pengaturan bangunan setempat dan rencana tata bangunan dan lingkungan.

\section{a) Rencana Tata Ruang Wilayah Nasional (RTRWN)}

Berdasarkan Permen PUPR No. 15 Tahun 2009 tentang Pedoman Penyusunan Rencana Tata Ruang Wilayah Provinsi, Rencana Umum Tata Ruang Nasional atau RTRWN merupakan arahan kebijakan dan strategi pemanfaatan ruang wilayah nasional yang disusun guna menjaga integritas nasional, keseimbangan, dan keserasian perkembangan antar wilayah dan antar sektor, serta keharmonisan antar lingkungan alam dengan lingkungan buatan untuk meningkatkan kesejahteraan masyarakat. RTRW Nasional disusun oleh Pemerintah Pusat dan menjadi acuan bagi Pemerintah Daerah. Penyusunan RTRWN harus memperhatikan wawasan nusantara dan ketahanan nasional; perkembangan permasalahan regional dan global, serta hasil pengkajian implikasi penataan ruang nasional; dan upaya pemerataan pembangunan dan pertumbuhan serta stabilitas ekonomi. Rencana rinci RTRW Nasional terdiri dari Rencana Tata Ruang Pulau dan Rencana Tata Ruang Kawasan
b) Rencana Tata Ruang Wilayah Provinsi (RTRWP)

RTRW Provinsi disusun oleh Pemerintah Provinsi. RTRWP merupakan rencana kebijakan operasional dari RTRWN yang berisi strategi pengembangan wilayah provinsi, melalui optimasi pemanfaatan sumber daya, sinkronisasi pengembangan sektor, koordinasi lintas wilayah kabupaten/kota dan sektor, serta pembagian peran dan fungsi kabupaten/kota di dalam pengembangan wilayah secara keseluruhan. Rencana rinci RTRWP terdiri dari RTR Kawasan Strategis Provinsi.

Penyusunan RTRW Provinsi sebagaimana tercantum dalam Pasal 6 Permen ATR/BPN No. 1 Tahun 2018 meliputi tahapan 1) Persiapan; 
Pengumpulan data dan informasi; 3) Pengolahan dan analisis data; 4) Penyusunan konsep; dan 5) Penyusunan dan pembahasan rancangan peraturan daerah tentang RTRW Provinsi. Dalam pasal 6 ayat 2 disebutkan bahwa penyusunan RTRW Provinsi dan RTRW Kabupaten/Kota diselesaikan dalam waktu paling lama 15 bulan yang terdiri atas: 1 (satu) bulan persiapan; 2 (dua) bulan pengumpulan data dan informasi; 5 (lima) bulan pengolahan dan analisis data; 6 (enam) bulan penyusunan konsep; dan 1 (satu) bulan penyusunan dan pembahasan rancangan peraturan daerah.

\section{c) Rencana Tata Ruang Wilayah Kabupaten/Kota}

Rencana umum tata ruang kabupaten/kota adalah penjabaran RTRW provinsi ke dalam kebijakan dan strategi pengembangan wilayah kabupaten/kota yang sesuai dengan fungsi dan peranannya di dalam rencana pengembangan wilayah provinsi secara keseluruhan, strategi pengembangan wilayah ini selanjutnya dituangkan ke dalam rencana struktur dan rencana pola ruang operasional. Rencana rinci tata ruang kabupaten/kota terdiri dari RDTR kabupaten/kota dan Rencana Tata Ruang Kawasan Strategis Kota. Ujung tombak perencanaan ruang di daerah adalah terletak pada RTRW kabupaten/kota yang selanjutnya disusun dalam bentuk Peraturan Daerah sehingga berkekuatan hukum. Pasal 78 UndangUndang Nomor 26 Tahun 2007 tentang Penataan Ruang mengamanatkan bahwa "semua Perda Kabupaten/Kota tentang RTRW Kabupaten/Kota disusun atau disesuaikan paling lambat dalam waktu 3 (tiga) tahun terhitung sejak UndangUndang ini diberlakukan”. Berdasarkan pasal tersebut maka Pemerintah Kabupaten Kota yang sudah memiliki Peraturan Daerah (Perda) tentang Rencana Tata Ruang Wilayah (RTRW) harus segera menyesuaikan muatan substansinya sesuai dengan peraturan perundang-undangan yang berlaku, sedangkan bagi pemerintah kabupaten/kota yang belum menyusun RTRW harus segera menyelesaikan Perda tentang RTRW kabupaten/kota maksimal tiga tahun setelah Undang-Undang Nomor 26 Tahun 2007 ditetapkan.

Sehubungan dengan muatan substansi yang harus dimuat RTRW kabupaten dan RTRW Kota telah diatur dalam Peraturan Menteri Pekerjaan Umum Nomor 16 Tahun 2009 tentang Pedoman Penyusunan Rencana Tata Ruang Wilayah Kabupaten dan Peraturan Menteri Pekerjaan Umum Nomor 17 Tahun 2009 tentang Pedoman Penyusunan Rencana Tata Ruang Wilayah Kota. Proses 
penetapan Perda RTRW merupakan suatu rangkaian kegiatan panjang yang dilakukan di daerah dan di pusat, kegiatan di daerah meliputi penyusunan materi teknis, penyusunan Rancangan Perda tentang RTRW, penyusunan naskah Kajian Lingkungan Hidup Strategis (KLHS), permohonan rekomendasi gubernur, dan penetapan Perda RTRW bersama dengan Dewan Perwakilan Rakyat Daerah (DPRD) sedangkan kegiatan di pusat meliputi pemeriksaan muatan substansi RTRW, pemeriksaan peta, pemeriksaan berita acara persetujuan tapal batas dengan wilayah tetangga, dan pemberian persetujuan substansi dari menteri yang membidangi tata ruang.

\section{b. Mekanisme}

Pengendalian

\section{Pemanfaatan Ruang}

Penegakan hukum pidana tata ruang merupakan bagian dari upaya pengendalian pemanfaatan ruang. Dalam struktur penyelenggaraan penataan ruang, pengendalian pemanfaatan ruang merupakan upaya-upaya yang menjamin terwujudnya kondisi ruang sebagaimana yang tercantum dalam tujuan penataan ruang. Dalam UUPR disebutkan, bahwa pengendalian pemanfaatan ruang diselenggarakan untuk menjamin terwujudnya tata ruang yang sesuai dengan rencana tata ruang. Pengendalian pemanfaatan ruang berkaitan erat dengan proses perencanaan dan pemanfaatan ruang.

Menjamin pemanfaatan ruang dapat berjalan sesuai dengan rencana tata ruang, dibutuhkan pengendalian pemanfaatan ruang yang meliputi peraturan zonasi, perizinan, insentif dan disinsentif serta pengenaan sanksi sebagaimana yang disebut dalam UUPR sebagai instrumen pengendalian pemanfaatan ruang.

Upaya pengendalian pemanfaatan ruang pada hakekatnya diperkuat dengan upaya penegakan hukum yang berupa pengenaan sanksi. Pengenaan sanksi terbagi menjadi dua, yaitu pengenaan sanksi administratif dan sanksi pidana. Sanksi administratif yang dapat dikenakan berdasarkan UUPR, yaitu: a. peringatan tertulis; b.penghentian sementara kegiatan; c. penghentian sementara pelayanan umum; d. penutupan lokasi; e.pencabutan izin; f. pembatalan izin; g. pembongkaran bangunan; h.pemulihan fungsi ruang; dan/atau i. denda administratif.

Selama ini pelanggaran terhadap rencana tata ruang lebih sering dikenakan sanksi administratif seperti pembongkaran bangunan maupun penutupan lokasi. Adapun pengenaan sanksi pidana dapat dikatakan sebagai upaya pamungkas dalam 
hal pengendalian sebagaimana yang disebutkan oleh Koeswadji bahwa penegakan hukum pada dasarnya merupakan ultimum remedium atau upaya penegakan hukum yang terakhir sebagai sebuah upaya untuk menghukum pelaku dengan hukuman penjara atau denda. Pengenaan sanksi pidana membutuhkan penyelidikan dan pendalaman kasus dari Penyidik Pegawai Negeri Sipil dengan pihak kepolisian. Kewenangan PPNS dalam proses tersebut tercantum dalam Pasal 68 UUPR. Kewenangan PPNS secara lengkap diatur dalam Permen ATR/Kepala BPN No. 3 Tahun 2017 tentang Penyidik Pegawai Negeri Sipil Penataan Ruang.

Permen ATR/Kepala BPN No. 3 Tahun 2017 tentang Penyidik Pegawai Negeri Sipil Penataan Ruang mengatur mengenai langkah-langkah PPNS Penataan Ruang dalam mengumpulkan bukti-bukti tindak pidana tata ruang. Serangkaian tindakan PPNS Penataan Ruang untuk mencari dan menemukan suatu peristiwa yang diduga sebagai tindak pidana di bidang penataan ruang guna menentukan dapat atau tidaknya dilakukan penyidikan sesuai dengan ketentuan peraturan perundangunda- ngan disebut dengan Wasmatlitrik (Pengawasan, Pengamatan, Penelitian atau Pemeriksaan). Wasmatlitrik dilaksanakan atas dasar adanya dugaan tindak pidana bidang penataan ruang. Dalam Pasal 28 Permen ATR/Kepala BPN No. 3 Tahun 2017.

Setelah dilakukan Wasmatlitrik, tahapan selanjutnya adalah melakukan penyidikan. Dalam Pasal 35 Permen ATR/Kepala BPN No. 3 Tahun 2017, diuraikan bahwa bentuk kegiatan penyidikan.

Perencanaan penyidikan oleh PPNS Penataan Ruang dibuat dengan menentukan a) sasaran penyidikan; b) sumber daya yang dilibatkan dan digunakan; c) cara bertindak; d) waktu yang akan digunakan, dan e) pengendalian penyidikan. Proses penyidikan juga meliputi pemanggilan sanksi, penangkapan, penahanan, penggeledahan, penyitaan, pemeriksaan, rekonstruksi atau reka ulang, pencegahan, serta penyelesaian dan penyerahan berkas perkara.

Setelah melaksanakan Wasmatlitrik, Direktorat Penertiban Pemanfaatan Ruang Direktorat Jenderal Pengendalian Pemanfaatan Ruang dan Penguasaan Tanah melaksanakan upaya penertiban pemanfaatan ruang

Implementasi kebijakan penegakan hukum pidana pada pelanggaran tata ruang diwilayah penelitian penulis adalah :

a) Dari aspek penyusunan Rencana Tata Ruang sudah sesuai Undang-Undang 
Nomor 26 Tahun 2007 tentang Penataan Ruang. Hal ini terlihat dengan telah ditetapkannya Rencana Tata Ruang Wilayah Nasional (RTRWN), Rencana Tata Ruang Wilayah Provinsi (RTRWP) dan Rencana Umum Tata Ruang Kabupaten/Kota (RUTR).

b) Dari aspek mekanisme pengendalian pemanfaatan ruang, walaupun sudah ditetapkan Peraturan Menteri Dalam Negeri Nomor 115 Tahun 2017 tentang Mekanisme Pengendalian dan Pemanfaatan Ruang dirasakan masih diperlukan pengaturan tentang 3R (Right, Rectriction, dan Responsibility). Sehingga setiap hal yang diberikan sebagai dasar pemanfaatan ruang (tanah) juga sudah ditetapkan pembatasanpembatasan dan tanggung jawab setiap pemegang hak atas tanah.

c) Dari aspek mekanisme pelaksanaan penegakan hukum pidana pada pelanggaran tata ruang juga telah dilengkapi dengan Peraturan Menteri Agraria dan Tata Ruang/Kepala Badan Pertanahan Nasional Nomor 3 Tahun 2017 tentang Penyidik Pegawai Negeri Sipil Penataan Ruang. d) Terkait dengan pengenanaan sanksi pidana pada pelanggaran terhadap rencana tata ruang, mayoritas responden, yaitu sebesar 56\% setuju dan $29 \%$ sangat setuju bahwa sanksi pidana tersebut apabila diterapkan akan efektif untuk mengendalikan pemanfaatan ruang.

e) Penegakan hukum pidana pada pelanggaran tata ruang belum efektif dapat dilaksanakan, karena tidak semua indikasi pelanggaran dapat identifikasi oleh satuan kerja yang bertanggung jawab. Berdasarkan data Data dari Direktorat Jenderal Pengendalian Pemanfaatan Ruang dan Penguasaan tanah, diperoleh data bahwa terdapat indikasi pelanggaran tata ruang di lokasi penelitian sebanyak 181 titik lokasi (DKI: 23 , Kabupaten Bogor: 94, Kabupaten Depok: 32, dan Kabupaten Cianjur: 32). dari sejumlah indikasi pelanggaran tersebut sampai sekarang belum dilaporkan tindak lanjut dengan Surat Peringatan (SP). Hal ini kemudian penanganannya tidak bisa dilanjutkan pada proses penyidikan. Hal lain yang juga menghambat adalah kesulitan pembuktian pidananya. Salah satu penyebab adalah tidak semua wilayah 
Kabupaten/ Kota mempunyai

Rencana Detail Tata Ruang dengan skala petanya 1:5000.

\section{Faktor-Faktor yang Berpengaruh} Terhadap Implementasi

Penegakan Hukum Pidana pada Pelanggaran Terhadap Rencana Tata Ruang dalam Rangka Pengendalian Pemanfaatan Ruang Berdasarkan sintesa dari literatur Soekanto dalam Maulido di atas, terdapat 5 faktor yang mempengaruhi penegakan hukum, yaitu faktor hukum, faktor penegak hukum, faktor sarana atau fasilitas pendukung, faktor masyarakat dan faktor kebudayaan. Namun, dari 5 faktor tersebut, faktor kebudayaan dan faktor masyarakat merujuk pada dasar yang sama yaitu perilaku masyarakat. Kebudayaan itu sendiri merupakan bagian yang tidak terpisahkan dari masyarakat. Untuk memvalidasi faktor-faktor yang berpengaruh pada penegakan hukum penataan ruang tersebut, sebelumnya dibutuhkan masukan dari para responden terkait prinsip mendasar antara faktor kebudayaan dan faktor masyarakat.

\section{a. Faktor Hukum}

Ditinjau dari faktor pertama yang paling berpengaruh adalah faktor hukum. Faktor hukum meliputi peraturan perundang-undangan seperti Undang- undang Dasar 1945, Undang-Undang, Peraturan Pemerintah (PP), Peraturan Presiden (Perpres), Peraturan Menteri (Permen), dan Peraturan Daerah (Perda). Dalam bidang penaatan ruang, ada beberapa peraturan perundangan terkait misalnya Undang-Undang No. 26 Tahun 2007 tentang Penataan Ruang, Peraturan Pemerintah Republik Indonesia Nomor 13 Tahun 2017 tentang Perubahan atas Peraturan Pemerintah Nomor 26 Tahun 2018 tentang Rencana Tata Ruang Wilayah Nasional, ataupun Peraturan Daerah (Perda) tentang rencana tata ruang di masing-masing provinsi atau kabupaten/kota.

Berdasarkan data yang dihimpun dari 102 responden, $29.4 \%$ responden sangat setuju dan $50 \%$ responden setuju bahwa peraturan perundang-undangan bidang penataan ruang saat ini sudah memenuhi syarat untuk menjadi dasar penegakan hukum terhadap tindak penataan ruang untuk pengendalian pemanfaatan tata ruang. Sementara sebagian kecil responden, yaitu $16,7 \%$ responden tidak setuju dan $2.9 \%$ responden menyatakan sangat setuju bahwa peraturan perundang-undangan yang ada saat ini sudah memenuhi syarat untuk menjadi dasar penegakan hukum terhadap tindak penataan ruang. 


\section{b. Faktor Penegak Hukum}

Faktor penegak hukum menjadi prioritas kedua yang berpengaruh pada penegakan hukum pidana pada pelanggaran rencana tata ruang. Penegak hukum merupakan aparat yang melaksanakan upaya untuk tegaknya atau berfungsinya norma-norma hukum secara nyata. Penegak hukum penataan ruang yang dimaksu dalam penelitian ini adalah Penyidik Pegawai Negeri Sipil (PPNS) Penataan Ruang. Untuk dapat melaksanakan tugasnya sebagai penegak hukum, terdapat 3 (tiga) indikator yang harus ditinjau yaitu kuantitatif, kualitatif serta pembiayaan operasional.

Berdasarkan persepsi responden ditemukan bahwa 39,2\% responden dan $16,7 \%$ responden setuju dan sangat setuju bahwa jumlah PPNS yang ada saat ini sudah memadai untuk melakukan penyidikan terhadap tindak pidana penataan ruang. Sementara, 33,3\% responden tidak setuju dengan pernyataan terseebut. Selebihnya $7,8 \%$ sangat tidak setuju dan $2.9 \%$ responden tidak memberikan jawaban.

\section{c. Faktor Sarana atau Fasilitas Pendukung}

Faktor prioritas ketiga yang memengaruhi penegakan hukum pidana pada pelanggaran terhadap rencana tata ruang adalah sarana atau fasilitas pendukung. Faktor sarana atau fasilitas pendukung dalam bidang tata ruang meliputi substansi fisik dan subtansi non fisik yang mendukung penegakan hukum penataan ruang, seperti Rencana Tata Ruang Wilayah (RTRW), Rencana Detail Tata Ruang (RDTR), serta instrumen pengendalian pemanfaatan ruang (Peraturan Zonasi, Perizinan, Insentif, Disinsentif dan Sanksi).

Indikator pertama yaitu Rencana Tata Ruang Wilayah (RTRW) dan Rencana Detail Tata Ruang (RDTR) mengingat daerah harus memiliki RTRW dan RDTR. Idealnya seluruh wilayah harus terpetakan dalam RTRW dan RDTR, tidak terkecuali Jabodetabekpunjur. Sebanyak 49\% responden setuju, bahwa seluruh wilayah Jabodetabekpunjur sudah benarbenar terpetakan dalam Rencana Tata Ruang Wilayah (RTRW dan RDTR), namun hanya $9.8 \%$ yang mantap menjawab sangat setuju terhadap indikator tersebut. Kemudian sebanyak 31,4\% responden menilai bahwa belum seluruh wilayah terpetakan dalam rencana tata ruang, serta ada 8,8\% responden yang sangat tidak setuju bahwa seluruh wilayah telah terpetakan.

\section{d. Faktor Masyarakat}


Faktor keempat hal yang paling berpengaruh pada penegakan hukum terhadap penataan ruang adalah masyarakat. Dalam Undang-Undang No. 26 Tahun 2007 tentang Penataan Ruang, terdapat bab yang khusus mengatur hak, kewajiban dan peran masyarakat dalam penataan ruang. Beberapa hak masyarakat adalah mengetahui rencana tata ruang, menikmai pertambahan nilai ruang sebagai akibat penataan ruang, memperoleh penggantian yang layak atas kerugian yang timbul akibat pelaksanaan kegiatan pembangunan yang sesuai dengan rencana tata ruang, mengajukan keberatan kepada pejabat berwenang terhadap pembangunan yang tidak sesuai dengan rencana tata ruang di wilayahnya, mengajukan tuntutan pembatalan izin dan penghentian pembangunan yang tidak sesuai dengan rencana tata ruang kepada pejabat berwenang dan mengajukan gugatan ganti kerugian kepada pemerintah dan/atau pemegan izin apabila kegiatan pembangunan yang tidak sesuai dengan rencana tata ruang menimbulkan kerugian.

Disimpulkan bahwa masyarakat memiliki peran yang penting dalam penegakan hukum penataan ruang. Hal ini yang menjadi perhatian para ahli untuk memprioritaskan peran masyarakat dalam penegakan hukum penataan ruang, karena sebenarnya peran masyarakat sudah tertulis di dalam Undang-Undang Penataan Ruang No 26 Tahun 2007 walaupun dalam pelaksanaannya peran masyarakat belum optimal dalam penegakan hukum penataan ruang, bahkan belum memahami rencana tata ruang di wilayahnya.

\section{e. Faktor Kelembagaan}

Prioritas kelima yang berpengaruh dalam penegakan hukum pidana pada pelanggaran rencana tata ruang adalah faktor kelembagaan. Kelembagaan merujuk pada institusi dan norma yang ada di dalamnya. Institusi atau kelembagaan di bidang hukum seperti lembaga pembuat hukum, lembaga penerap hukum, kepolisian, kejaksaan, pengadilan dan lembaga koreksi. Dalam bidang penataan ruang, kelembagaan yang sangat penting juga termasuk di dalamnya adalah pemerintah daerah, baik provinsi maupun kabupaten/kota mengingat kewajiban masing-masing daerah yang menyelenggarakan rencana tata ruang. Seperti yang telah disampaikan sebelumnya, bahwa PPNS penataan ruang juga perlu dilembagakan untuk memaksimalkan dan mengoptimalkan peran dan fungsinya agar berjalan maksimal.

Berdasarkan hasil kuesioner, mayoritas responden (50\%) setuju bahwa 
kelembagaan yang ada saat ini sudah sesuai untuk melaksanakan penegakan hukum penataan ruang. Sebaliknya $32,4 \%$ responden tidak setuju bahwa saat ini kelembagaan sudah sesuai. Sementara $11,1 \%$ responden sangat setuju dan $3,9 \%$ sangat tidak setuju. Berikut adalah grafik yang menggambarkan hasil persebaran persepsi responden.

\section{f. Faktor Kebudayaan}

Faktor yang terakhir diprioritaskan oleh responden adalah faktor kebudayaan. Faktor kebudayaan ini sebenarnya terkait dengan faktor masyarakat. Hal tersebut dikarenakan kebudayaan sebagai pengontrol perilaku manusia, seperti bagaimana manusia harus bertindak, berbuat atau bersikap terhadap orang lain. Dalam hal penataan ruang, faktor kebudayaan ini mempengaruhi sikap masyarakat dalam penegakan peraturan tata ruang serta tindakan masyarakat untuk memanfaatkan ruang sesuai rencana tata ruang.

Faktor kebudayaan masyarakat dinilai oleh mayoritas responden belum menunjang penegakan sanksi pidana terhadap pelanggaran rencana tata ruang. Hal ini ditunjukan dengan sebanyak $47,1 \%$ responden tidak setuju, bahwa faktor kebudayaan masyarakat sudah menunjang penegakan sanksi pidana terhadap pelanggaran rencana tata ruang.

\section{Kebijakan}

Pengendalian

Pemanfaatan Ruang yang dapat Efektif diberlakukan Melalui Penegakan Hukum Pidana pada Pelanggaran Terhadap Rencana Tata Ruang

Penyusunan

kebijakan

pengendalian pemanfaatan ruang melalui penegakan hukum pidana pada pelanggaran tata ruang akan disusun dengan prinsip 3R yaitu prinsip melindungi Rights (hak-hak atas tanah) masyarakat, sekaligus meningkatkan Responsibilities masyarakat agar ikut mendukung/ memperkuat upaya-upaya penegakan hukum dalam rangka pengendalian pemanfaatan ruang (Restriction). Terhadap 6 (enam) faktor yang mempengaruhi penegakan hukum di Indonesia yaitu faktor hukum, faktor penegak hukum, faktor sarana atau fasilitas pendukung, faktor masyarakat dan faktor kebudayaan, dan faktor kelembagaan, diperlukan adanya suatu pengembangan/intervensi. Pengembangan tersebut diintegrasikan menjadi suatu model penyusunan konsep kebijakan pengendalian pemanfaatan ruang melalui penegakan hukum pidana yang efektif dapat diterapkan. 
Kebijakan Pengendalian

Pemanfaatan Ruang melalui Penegakan Hukum Pidana Tata Ruang, adalah sebagai berikut:

1) Faktor hukum dan faktor masyarakat berbanding lurus, artinya apabila hukum kuat, baik dan efektif maka masyarakat juga akan lebih tertib dalam menerapkan hukum tersebut;

2) Faktor hukum yang kuat/baik dan efektif harus mengandung 3R, yaitu kepastian akan hak (Right), kepastian akan batasan (Rectriction) dan kepastian akan tanggung jawab (Responsibility) pemegang hak. Prinsip 3R tersebut harus dicantumkan dalam dasar pemanfaatan ruang/tanah.

3) Hukum baru dapat diterapkan apabila ditunjang oleh kelembagaan yang tepat,

penegak hukum yang cakap dari segi jumlah dan kualitas serta sarana dan prasarana pendukung yang cukup.

4) Nomor 1, 2 dan 3 adalah satu kesatuan sistem yang tidak dapat terpisahkan.

\section{PENUTUP}

\section{Simpulan}

1. Implementasi kebijakan penegakan hukum pidana apabila ditinjau dari proses penyusunan rencana tata ruang dan mekanisme pengendalian pemanfaatan ruang sudah dilakukan sesuai dengan Undang-Undang Nomor 26 Tahun 2007 tentang Penataan Ruang. Dari aspek penegakan hukum pidana pada pelanggaran tata ruang dalam rangka untuk pengendalian pemanfaatan ruang belum berjalan secara efektif. Hal ini terbukti sampai dengan sekarang belum ada pelanggaran tata ruang yang diberikan sanksi pidana di wilayah daerah penelitian. Salah satu penyebab pengenaan sanksi pidana adalah adanya kesulitan proses pembuktian tindak pidana penataan ruang.

2. Faktor-faktor yang berpengaruh terhadap implementasi penegakan hukum pidana pada pelanggaran terhadap rencana tata ruang dalam rangka pengendalian pemanfaatan ruang ada 6 (enam) yang disusun berdasarkan peringkat yaitu faktor hukum, faktor penegak hukum, faktor sarana atau fasilitas pendukung, faktor masyarakat atau kebudayaan, dan faktor kelembagaan. Faktor kelembagaan merupakan faktor tambahan diluar 5 (lima) faktor yang dikemukakan oleh Soekanto. Mayoritas responden setuju jika faktor kelembagaan menjadi salah satu faktor penegakan hukum pada pelanggaran terhadap rencana tata ruang. Masing- 
masing faktor memiliki permasalahan masing-masing. Terkait faktor hukum, peraturan perundang-undangan yang ada saat ini belum mempermudah proses pembuktian tindak pidana penataan ruang. Terkait faktor penegak hukum, kualitas dan anggaran untuk PPNS sebagai penegak hukum kurang memadai. Terkait sarana atau fasilitas pendukung, kondisinya cukup baik. terkait masyarakat, kepedulian masyarakat terhadap hukum penataan ruang masih rendah. Terkait kebudayaan, budaya masyarakat belum selaras/ sesuai dengan rencana tata ruang wilayah. Terkait kelembagaan, kelembagaan sudah cukup baik, namun upaya penegakan hukum masih mengalami kesulitan.

3. Kebijakan pengendalian pemanfaatan ruang yang dapat efektif diberlakukan melalui penegakan hukum pidana pada pelanggaran terhadap rencana tata ruang adalah sebagai berikut:

1) Faktor-faktor yang harus diperhatikan :

a) Faktor hukum: perlu petunjuk teknis mengenai tata cara pembuktian hukum pidana pada pelanggaran tata ruang. Walaupun dari aspek peraturan perundang-undangan sudah dianggap memenuhi syarat sebagai dasar penegakan hokum terhadap tindak pidana penataan ruang.

b) Faktor Penegak hukum: perlu peningkatan PPNS Tata Ruang baik terkait dengan kuantitas maupun kualitasnya.

c) Faktor Sarana atau Fasilitas pendukung: perlu ditingkatkan cakupan peta rencana tata ruang terutama yang berskala detail.

d) Faktor masyarakat: perlu ditingkatkan upaya kesadaran atau kepedulian masyarakat akan pentingnya pemanfaatan ruang sesuai rencana tata ruang wilayah.

e) Faktor kebudayaan: perlu diupayakan suatu gerakan yang dapat menjadikan pemanfaatan ruang sesuai dengan rencana tata ruang wilayah menjadi kebudayaan masyarakat.

f) Faktor kelembagaan: Perlu diatur independensi PPNS tata ruang dalam bentuk peraturan perundang-undangan yang tidak lagi bertanggung jawab langsung kepada Bupati/Walikota pada wilayah Kabupaten/Kota. 
2) Kebijakan pengendalian pemanfaatan ruang dapat efektif diterapkan melalui penegakan hukum pidana pada pelanggaran rencana tata ruang adalah harus memperhatikan prinsip 3R (Right, Rectriction, Responsibility).

\section{Saran}

Untuk mewujudkan pengendalian pemanfaatan ruang yang optimal di Jabodetabek, maka ada beberapa saran yang dapat penulis susun.

1. Pemerintah

Saran untuk Pemerintah:

a) Meningkatkan kualitas penegak hukum terutama PPNS melalui pendidikan dan latihan sehingga PPNS memiliki kemampuan yang lebih baik untuk melakukan upaya penegakan hukum.

b) Meningkatkan anggaran untuk PPNS sehingga PPNS mampu melakukan operasional dengan baik.

c) Perlu memperbaiki struktur kelembagaan penataan ruang mengingat lembaga yang menangani pengendalian pemanfaatan ruang di daerah memiliki peran yang minim. Struktur organisasi perangkat daerah juga belum linier dengan Pemerintah Pusat.

2. Swasta

Saran untuk pihak swasta:

a) Pihak swasta yang ingin melakukan pembangunan harus sesuai dengan rencana tata ruang dan mengikuti peraturan yang berlaku sehingga tertib tata ruang dapat diwujudkan.

b) Pihak swasta diharapkan bersikap proaktif terhadap pemahaman penegakan hukum dalam rangka pengendalian pemanfaatan ruang.

3. Masyarakat

Saran untuk masyarakat:

a) Masyarakat diharapkan proaktif untuk meningkatkan pemahaman penegakan hukum dalam rangka pengendalian pemanfaatan ruang.

b) Pembentukan kelompok-kelompok masyarakat pengendalian pemanfaatan ruang sangat bisa dilakukan untuk membantu mengawasi berjalannya rencana tata ruang wilayah sehingga apabila terjadi indikasi pelanggaran, masyarakat langsung dapat melaporkannya kepada PPNS.

\section{DAFTAR PUSTAKA}

Ahmad Jazuli, Penegakan Hukum Penataan Ruang dalam Rangka Mewujudkan Pembangunan 
Berkelanjutan, Jurnal Rechts Vinding: Media Pembinaan Hukum Nasional, 6 (2), 2017.

Andi Renald, Kota Resilien Mewujudkan Jakarta Bebas Banjir, Dirjen Pengendalian Pemanfaatan Ruang dan Penguasaan Tanah, 2017.

Anugerah Perkasa. Pelanggaran Tata Ruang: Data 194 Perusahaan di Kalteng dan Kalbar Diserahkan ke KPK. 2015. Diakses pada 6 Januari 2017, dari http://kabar24. bisnis.com/read/20151105/16/489 $087 /$.

Boedi Harsono, Hukum Agraria Indonesia: Himpunan Peraturan-Peraturan Hukum Tanah, Djambatan, Jakarta, 2008.

Laporan Akhir Pelaksanaan Pengawasan dan Pengendalian Pemanfaatan Pemanfaatan Ruang Jabodetabekpunjur, Kementerian Pekerjaan Umum, Jakarta, Tahun 2013.

Mohamad Soerjani, Ekologi Manusia, Reduction Climet Change, Adative Capacity and Development, Universitas Terbuka, Tangerang-Jakarta, 2002.
Oto Sumarwoto, Ekologi, Lingkungan Hidup, dan Pembangunan, Alumni, Jakarta, 1997.

Sonny Keraf, Etika Lingkungan Hidup, Kompas, 2002. 
Andi Tenrisau, Kebijakan Pengendalian Pemanfaatan Ruang Melalui Penegakan Hukum Pidana Pada... 